\title{
Cumulative Corticosteroid Doses and Osteoporosis in Patients with Multiple Sclerosis
}

\author{
Multipl Sklerozlu Hastalarda Kümülatif Kortikosteroid Dozu ve Osteoporoz
}

\author{
Şule Arslan', Reyhan Çeliker ${ }^{2}$, Rana Karabudak ${ }^{3}$ \\ ${ }^{1}$ Gaziosmanpaşa Üniversitesi, Fiziksel Tıp ve Rehabilitasyon Anabilim Dalı, Tokat, Turkey \\ ${ }^{2}$ Acıbadem Üniversitesi, Fiziksel Tıp ve Rehabilitasyon Anabilim Dalı, İstanbul, Turkey \\ ${ }^{3}$ Hacettepe Üniversitesi, Nöroloji Anabilim Dalı, Ankara, Turkey
}

\begin{abstract}
Objective: Multiple sclerosis (MS) is an inflammatory demyelinating disorder and corticosteroids used for the treatment of attacks are known to cause osteoporosis. Although osteoporosis is a known potential complication, many patients do not receive treatment to prevent bone loss. The aim of this study was to assess the relationship between cumulative doses of corticosteroids and bone mineral density (BMD) in MS patients.
\end{abstract}

Materials and Methods: Twenty-two patients with MS (15 women, 7 men) and 22 age- and sex-matched subjects were enrolled into the study. Lumbar and femoral BMDs were measured using dual energy X-ray absorptiometry (DXA). Mobility and ambulation scales were also evaluated. Corticosteroid use was determined from an interviewer-administered questionnaire and patient records.

Result: Lumbar and femoral BMDs were significantly lower in MS patients compared to the control group $(p<0.05) .18 .2 \%$ of the MS patients had no restriction in activities of normal employment and domestic life when assessed with Kraft Mobility Scale. Only 22.7\% of the MS patients were fully ambulant when evaluated with Scranton Ambulation Scale. Cumulative dose was negatively correlated with lumbar BMD measurements $(r=-0.505, p=0.017)$.

Conclusion: Corticosteroids are an important part of the MS therapy and their use results in osteoporosis. Thus, cumulative corticosteroid dose should be determined and BMD measurements of the patients should be taken before treatment to determine those at high risk of osteoporosis, and preventive measures should be undertaken. (Turk J Rheumatol 2010; 25: 191-5)

Key words: Bone mineral density, corticosteroids, multiple sclerosis, osteoporosis

Received: 25.03 .2009

Accepted: 09.11.2009

\section{Özet}

Amaç: Multipl Skleroz (MS) inflammatuar demiyelinizan bir hastalıktır ve atakların tedavisinde kullanılan kortikosteroidlerin osteoporoza neden olduğu bilinmektedir. Osteoporoz bilinen potansiyel bir komplikasyon olmasına rağmen birçok hasta kemik kaybını önlemeye yönelik tedavi almamaktadır. Bu çalıșmanın amacı MS'li hastalarda kümülatif kortikosteroid dozu ve kemik mineral yoğunluğu (KMY) arasındaki ilișkiyi değerlendirmekti.

Yöntem ve Gereçler: MS'li 22 hasta (15 kadın, 7 erkek) ve 22 yaș ve cinsiyet uyumlu birey çalıșmaya dahil edildi. Lomber ve femoral KMY dual enerji X-Ray absorbsiyometri (DXA) ile ölçüldü. Mobilite ve ambulasyon skalaları değerlendirildi. Kullanılan kortikosteroidler, hasta kayıtları ve görüșmeci tarafından uygulanan anket ile belirlendi.

Bulgular: Lomber ve femoral KMY MS'li hastalarda kontrol grubuna kıyasla daha düșüktü $(p<0.05)$. Kraft Mobilite Skalası ile değerlendirildiğinde MS'li hastaların \% 18.2'sinde normal mesleki ve ev içi aktivitelerde kısıtlılık yoktu. Scranton Ambulasyon Skalası ile değerlendirildiğinde MS'li hastaların sadece \%22.7'si ambulatuardı. Kümülatif kortikosteroid dozu lomber KMY ölçümleri ile negatif korelasyon gösteriyordu ( $r=-0.505, p=0.017)$.

Sonuç: Kortikosteroidlerin MS tedavisinin önemli bir parçası olması ve kortikosteroid kullanımının osteoporoz ile sonuçlanması nedeniyle, tedavi öncesinde osteoporoz açısından yüksek riskli hastaların saptanması için hastanın kullandığı kümülatif steroid dozu belirlenmeli, KMY ölçümü yapılmalıdır ve koruyucu önlemler alınmalıdır. (Turk J Rheumatol 2010; 25: 191-5)

Anahtar sözcükler: Kemik mineral yoğunluğu, kortikosteroid, multipl skleroz, osteoporoz

Alındığı Tarih: 25.03.2009 Kabul Tarihi: 09.11.2009

Address for Correspondence: Dr. Şule Arslan, Gaziosmanpaşa Üniversitesi, Fiziksel Tıp ve Rehabilitasyon Anabilim Dalı, Tokat, Turkey Phone: +903562129500 E-mail: sulearslan71@hotmail.com

doi: $10.5152 /$ tjr. 2010.27 


\section{Introduction}

Osteoporosis is characterized by low bone mass and microarchitectural deterioration of bone tissue leading to enhanced bone fragility and a consequent increase in fracture risk. As established osteoporosis is difficult to treat, the aim should be prevention, including the identification and prevention of secondary causes (1). Steroid-induced osteoporosis is the leading form of secondary osteoporosis (2). Corticosteroids are used for the long-term treatment of many diseases including hepatic, gastrointestinal, neurologic, rheumatologic, renal, and pulmonary disorders. Walsh et al. (1) reported that $0.5 \%$ of the total population (aged $12-94$ years) and $1.4 \%$ of patients aged 55 years or more had been taking oral steroid treatment for at least three months.

Supraphysiologic concentrations of corticosteroids suppress osteocalcin concentrations, and this effect can be observed after five days of therapy (3). Bone loss is generally rapid during the first six months of glucocorticoid treatment, with an average decrease of $5 \%$ over the first year of long-term treatment (4). Thereafter, bone loss is $1 \%$ to $2 \%$ per year. Corticosteroid excess causes rapid and significant impairment of the bone quality (2). Such quality is subserved by bone matrix, microarchitecture, rate of bone turnover, and mechanostatic adaptation, which in turn depend on the osteocyte network. Glucocorticoids decrease the number and the function of osteoblasts, which leads to a suppression of bone formation (5). The replication of cells of the osteoblastic lineage is decreased, reducing the pool of cells that may differentiate into mature osteoblasts. In addition, glucocorticoids inhibit osteoblast-driven synthesis of type I collagen, the major component of the bone extracellular matrix, with a consequent decrease in bone matrix available for mineralization. The function of osteocytes is affected by modification of the elastic modulus surrounding osteocytic lacunae. Additionally, glucocorticoids induce the apoptosis of osteocytes. As a result, the normal maintenance of bone through this mechanism is impaired and the biomechanical properties of bone are compromised. Intestinal calcium absorption is also inhibited by glucocorticoids (5). Bone loss may be reversible after steroid withdrawal in young people, as evaluated by quantitative computed tomography (6).

Although osteoporosis risk increases during corticosteroid therapy, many underlying diseases negatively affect bone health and compound the effect of steroids. Risk factors such as hypogonadism, malnutrition and physical inactivity are complications of diseases that are caused by the disease itself rather than the treatment (4). Steroid- induced osteoporosis is a serious health problem that may result in significant long-term morbidity if preventive measures are not taken.
Corticosteroids, especially methylprednisolone, have a substantial treatment effect on the attacks of multiple sclerosis (MS) (7). Even though short courses of intravenous (i.v.) or oral corticosteroids seem safe, complications are not rare, particularly in MS patients who are at additional risk for osteoporosis because of their inactivity. Steroidinduced osteoporosis contributes to a significant increase in morbidity for individuals who may already have substantial disability as a result of their primary disease (8). Despite the risk of steroid-induced osteoporosis in patients receiving long-term treatment, its prevention and treatment remain neglected. Many patients receiving or initiating long-term glucocorticoid therapy do not undergo bone mineral density (BMD) measurement or receive specific preventive or therapeutic agents when indicated (5).

Adverse events related to the corticosteroid treatment are not reduced by alternate-day administration, and there are some conflicting results about the effects of daily dose, cumulative dose and duration of corticosteroid treatment on the rate of bone loss $(4,9)$. The aim of this study was to determine the relationship between BMD and cumulative corticosteroid dose in MS patients.

\section{Materials and Methods}

Twenty-two clinically definite MS patients (criteria by Poser et al.) and 22 age- and gender-matched control subjects were enrolled into the study. Control subjects were recruited from a cohort of healthy individuals taking no known bone-active medications. Subjects with any secondary causes of osteoporosis such as hyperparathyroidism or hyperthyroidism were excluded from the study. Patients and controls underwent an extensive interview including risk factors for osteoporosis, corticosteroid use and MS symptoms. Cumulative dose was determined from an interviewer-administered questionnaire and patient records.

Lumbar and thoracic spine X-rays were taken in MS patients to exclude a compression fracture. Lumbar and femoral BMDs were measured using dual energy X-ray absorptiometry (DXA) by Hologic QDR 4500-A (V8.20f:3). A Z-score of -2.0 or lower is defined as "below the expected range for age" in females prior to menopause and males younger than age 50 (10). Anthropometric measurements and biochemical analysis were also done. Scranton and Kraft Mobility Scales were used to assess ambulation and mobility levels of MS patients $(11,12)$. Kurtzke Expanded Disability Status Scale (EDSS) was also used (13).

\section{Statistical analysis}

Descriptive statistics are reported as the mean \pm SD for all variables unless otherwise stated. Baseline descriptive characteristics and BMD measurements were compared with Mann-Whitney $U$ test. Spearman rank correlations were determined between baseline BMD measurements, 
disability level measured by Kurtzke EDSS and cumulative corticosteroid dose (methylprednisolone).

\section{Results}

The MS group included 15 female and 7 male patients. The mean age of the MS patients was $35.5 \pm 9.0$ years. The data including age, body mass index (BMI), EDSS scores, and ambulation and mobility scales are summarized in Table 1.

Body mass index (BMI) was higher in the control group compared to MS patients $(p<0.05)$. There was no fracture in MS patients and mean methylprednisolone dose was $9.9 \pm 6.5 \mathrm{~g}$. Lumbar and femoral BMDs were significantly lower in MS patients compared to the control group $(p<0.05)$ (Figure 1, Table 2).

Lumbar total BMD was below the expected range for age in 9 MS patients (40.9\%). Regarding the hip total BMD measurements, 12 MS patients $(54.5 \%)$ had BMDs below the expected range for age. In the control group, these measurements were within the expected range for age. $18.2 \%$ of the MS patients had no restriction on activities of normal employment and domestic life when assessed with Kraft Mobility Scale. Only $22.7 \%$ of the MS patients were fully ambulant when evaluated with Scranton Ambulation Scale. Disease duration was not correlated with BMD measurements.

Cumulative dose was not statistically different between patients who needed unilateral or bilateral assistance for

Table 1. Some characteristics of the study population

\begin{tabular}{lcc}
\hline & $\begin{array}{c}\text { MS Group } \\
(\mathbf{n}=22) \\
\text { Mean } \pm \text { SD }\end{array}$ & $\begin{array}{c}\text { Control Group } \\
(\mathbf{n}=22) \\
\text { Mean } \pm \text { SD }\end{array}$ \\
\hline Age (years) & $35.5 \pm 9.0$ & $35.7 \pm 9.0$ \\
BMI $\left(\mathrm{kg} / \mathrm{m}^{2}\right)$ & $21.4 \pm 2.7$ & $25.9 \pm 3.8$ \\
EDSS score (0-10) & $4.6 \pm 2.4$ & \\
Scranton scale (1-7) & $3.2 \pm 1.9$ & \\
Kraft scale (1-7) & $2.8 \pm 1.5$ & \\
\hline $\begin{array}{l}\text { MS: Multiple sclerosis, BMI: Body mass index, EDSS: Expanded } \\
\text { disability status scale }\end{array}$ & \\
\hline
\end{tabular}

ambulation (EDSS score $>5.5$ ) and those with better ambulation (10.1 $\pm 6.1 \mathrm{~g}$ and $9.7 \pm 7.4 \mathrm{~g}$, respectively). Lumbar total BMD, femoral neck and femoral total BMD were also not statistically different between these groups. Although EDSS score and mobility and ambulation levels were not statistically different for patients receiving different corticosteroid doses, lumbar total BMD was significantly lower in patients receiving cumulative dose over $10 \mathrm{~g}$. Cumulative dose was negatively correlated with lumbar BMD measurements ( $r=-0.505, p=0.017)$.

\section{Discussion}

The relationship between BMD, cumulative dose of corticosteroid and disability was evaluated in this study. Lumbar and femoral BMDs were significantly lower in MS patients compared to the control group and cumulative dose was negatively correlated with lumbar BMD measurements.

Cosman et al. (15) found a correlation between bone loss rates and steroid exposure. Since steroid courses were almost uniform, steroid exposure was defined as duration of treatment. In the femoral neck, bone loss rates in MS patients varied from more than $3 \%$ per year to more than $7 \%$ per year. These losses were three- to six-fold higher

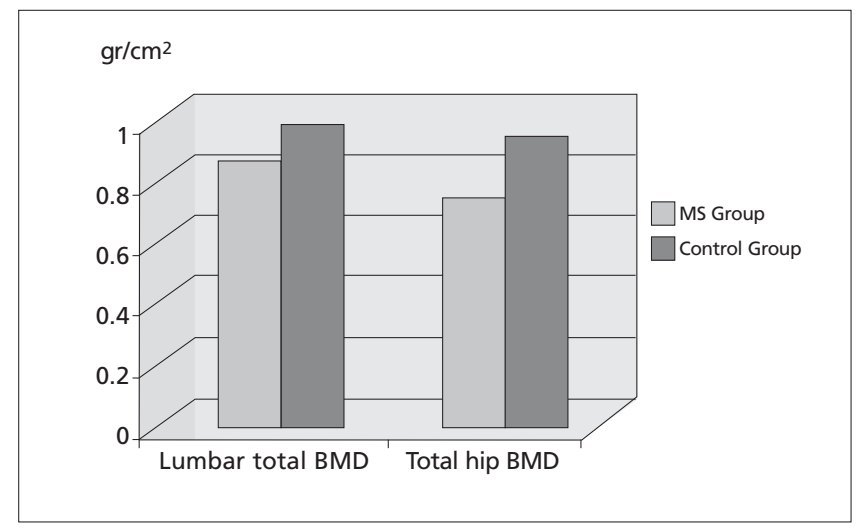

Figure 1. Comparison of lumbar total and hip total BMDs in the MS and control groups

\begin{tabular}{|c|c|c|c|}
\hline & $\begin{array}{l}\text { MS Group } \\
(n=22)\end{array}$ & $\begin{array}{l}\text { Control Group } \\
\qquad(n=22)\end{array}$ & $p$ \\
\hline Lumbar total BMD $\left(\mathrm{g} / \mathrm{cm}^{2}\right)$ & $0.901(0.750 / 1.037)$ & $0.988(0.834 / 1.209)$ & $<0.05$ \\
\hline Lumbar total Z- Scores & $-1.7(-2.8 /-0.2)$ & $-0.7(-1.7 / 1.1)$ & \\
\hline Lumbar total T- Scores & $-1.6(-2.6 / 0.6)$ & $-0.7(-1.9 / 1.5)$ & \\
\hline Femur neck BMD $\left(\mathrm{g} / \mathrm{cm}^{2}\right)$ & $0.707(0.493 / 0.871)$ & $0.849(0.664 / 1.140)$ & $<0.05$ \\
\hline Femur neck Z- Scores & $-1.8(-3.2 / 0.0)$ & $-0.3(-2.0 / 1.7)$ & \\
\hline Femur neck T- Scores & $-2.2(-4.0 /-0.2)$ & $-0.9(-2.3 / 1.5)$ & \\
\hline Hip total BMD $\left(\mathrm{g} / \mathrm{cm}^{2}\right)$ & $0.753(0.494 / 0.951)$ & $0.962(0.734 / 1.214)$ & $<0.05$ \\
\hline Hip total Z- Scores & $-2.1(-3.3 /-0.1)$ & $-0.0(-1.9 / 2.2)$ & \\
\hline Hip total T- Scores & $-2.2(-4.0 /-0.3)$ & $-0.4(-2.0 / 1.0)$ & \\
\hline
\end{tabular}

Results are given as median (minimum/maximum values), MS: Multiple sclerosis, BMD: Bone mineral density 
than losses seen in the control populations $(p<0.01$ for postmenopausal women and men with MS versus respective controls; $p=0.2$ for premenopausal MS patients versus controls). Mean duration of steroid exposure was 5.0 \pm 0.7 months in all patients with $\mathrm{MS}$, which was relatively short compared to other studies. When evaluating bone loss rate according to steroid treatment duration above and below the mean, low steroid exposure was associated with spine losses of $0.8 \%$ and hip losses of $4.4 \%$, whereas high steroid exposure was associated with losses of $3.7 \%$ for spine and $7.4 \%$ for hip. These differences, however, did not meet statistical significance $(p=0.08$ to $0.17)$. In our study, cumulative dose was evaluated instead of exposure duration. Cosman et al. (15) reported that mean EDSS scores were 6.5 for premenopausal women with MS, 6.3 for postmenopausal women with MS, and 7.0 for men with MS. EDSS score correlated with bone-loss rate in the femoral neck $(r=-0.38, p=0.02)$ and in the spine $(r=-0.40, p=0.02)$. Our patients were younger and less disabled with a mean \pm SD EDSS score of $5.6 \pm 2.0$ for men and $4.1 \pm 2.5$ for women with MS.

Formica et al. (16) conducted a study to determine whether ambulation ability or glucocorticoid use is associated with bone mass and/or fat-free mass (FFM). Seventy-one female MS patients were compared to healthy age- and gender-matched controls. MS patients were divided into two groups as ambulatory (EDSS score $0-6.5$ ) and non-ambulatory (EDSS score >6.5). Similar to Cosman et al.'s study (15), glucocorticoid use was expressed as duration of the use (months). Compared to age-matched controls, MS patients had deficits in total body bone mineral content (TBBMC) and total body FFM when expressed as Z- scores, but not when expressed in absolute values. After adjustment for the deficit in FFM, TBBMC was not significantly different in patients with MS as compared to controls. EDSS score was negatively associated with TBBMC. When compared to ambulatory MS patients, non-ambulatory patients had a deficit in TBBMC whether expressed in absolute terms or as standardized score. Comparing ambulatory MS patients to non-ambulatory MS patients, difference in duration of corticosteroid use was statistically not significant. We also found that cumulative dose was not statistically different between patients who needed unilateral or bilateral assistance for ambulation and those with better ambulation. In Formica et al.'s (16) research, ambulatory patients (54.9\% of the MS patients) had no difference in bone mass or body composition compared to the control subjects, suggesting that either the time since diagnosis or the disease process was different. Corticosteroid use had minimal effects on bone mass in mobile patients. Non-ambulatory patients might have a more severe disease condition, with immobility and corticosteroid use accentuating the deficit in bone mass. In our study population, lumbar and femoral BMDs were significantly lower in MS patients compared to the control group.
In a prospective study, BMD following a single corticosteroid pulse was measured using DXA (16). Patients who received any steroid treatment six months prior to enrollment were excluded. BMDs at lumbar spine and proximal femur were measured at baseline and 2, 4 and 6 months. Correlations between baseline BMD and corticosteroid pulses received by patients in the past 1, 3, 5 and 10 years were also examined. Baseline BMDs were normal in the lumbar region, but reduced at the femoral neck after accounting for the expected effects of age, sex, race, and body weight on BMD in the healthy population. The strongest relationship was seen between femoral neck density and baseline disability. Patients who needed unilateral or bilateral assistance for ambulation (median EDSS score $>5.5$ during the study period) lost $1.6 \%$ of their baseline femoral neck BMD 6 months after steroid pulse, while those with better ambulation gained $2.9 \%$. Correlations between BMD and age, disease duration, baseline disability, and the number of corticosteroid pulses in the past 1, 3, 5 and 10 years were statistically not significant. Mean EDSS score was 5.18 $\pm 1.26 .46 .7 \%$ (14/30) of patients had EDSS scores $>5.5$. The dichotomy between corticosteroid pulse effects on lumbar and femoral neck BMD is not typical of bone density changes seen in aging, endocrine diseases or long-term steroid use, but has been reported in patients with spinal cord injuries. In patients with spinal cord injuries, this difference has been attributed to changes in weight-bearing on the two skeletal regions. Patients with MS have similar mobility changes, especially at higher EDSS scores.

The rate of bone loss has been related to daily steroid dose, duration of treatment and cumulative dose, while some studies failed to find such an association. This may be a problem of methodology. Zorzon et al. (18) studied the effect of high-dose methylprednisolone (HDMP) pulses on BMD in 43 MS patients and found no correlation between BMD measurements and lifetime methylprednisolone dosage. BMD was measured by DXA (Hologic QDR 2000) at the lumbar spine (L2-4) and femoral neck. BMD measurements were performed 18-24 months (median 21) after the conclusion of a phase II trial of HDMP in patients with relapsing remitting MS. Mean EDSS score was $1.6 \pm 13$ (1.0-6.0) in the pulsed HDMP group, and 2.8 2.1 (1.0-6.0) in the HDMP for relapses group. The average lifetime dosage of methylprednisolone was $75.4 \pm 11.9$ in the pulsed HDMP group and $28.6 \pm 18.3$ in the HDMP for relapses group. All patients were able to walk. $90.7 \%$ of the patients had a relapsing remitting course and $9.3 \%$ had a secondary progressive form. Contrary to our study, MS patients had better ambulation, and BMDs at the lumbar spine and femoral neck did not differ in MS patients and controls. In partial correlation analysis, femoral neck BMD was inversely correlated with EDSS score after controlling for age, gender and menopausal status. EDSS scores were $1.6 \pm 1.3$ in patients treated with HDMP pulses and $2.8 \pm 2.1$ in patients receiving 
methylprednisolone only for relapses. Patients on regular methylprednisolone pulses and patients receiving HDMP only for relapses had comparable BMD despite the marked difference in cumulative methylprednisolone dose (75.4 g vs. $28.6 \mathrm{~g}$ ). Considering only the subgroup of patients with EDSS $<5.5$, they found a significant inverse correlation between BMD at the femoral neck and EDSS score in both groups. Two (4.7\%) MS patients and 4 $(6.6 \%)$ of the healthy subjects in the control group had osteoporosis. Osteopenia was present in 25 (58.1\%) MS patients and 21 (34.4\%) healthy subjects. Zorzon et al. (18) found only minor differences in BMD between patients with MS and healthy controls. The discrepancy in results might be because of the different characteristics of the study populations. Unlike chronic corticosteroid therapy, which induces osteoporosis, intermittent administration of short HDMP pulses does not promote bone loss and/or permits recovery of BMD without permanent skeletal damage.

Several but not all studies have demonstrated that steroid-induced bone loss is dependent on the cumulative amount of corticosteroid used. The minimum cumulative dose necessary to produce bone loss in adults has not been estimated. In this study, we found that lumbar total BMD was significantly lower in patients receiving cumulative corticosteroid doses over $10 \mathrm{~g}$. Cumulative steroid dose appears to constitute a major risk factor for bone loss, and osteoporosis may be expected to occur in all individuals who take excess amounts of corticosteroids for long periods. Corticosteroids are an important part of the MS therapy and corticosteroid use results in osteoporosis. Thus, BMD measurements of the patients should be taken before treatment to determine those at high risk for osteoporosis, and preventive measures should be undertaken.

\section{Conflict of Interest}

No conflict of interest declared by the authors.

\section{References}

1. Walsh LJ, Wong CA, Pringle M, Tattersfield AE. Use of oral corticosteroids in the community and the prevention of secondary osteoporosis: a cross sectional study. BMJ 1996; 313: 344-6.

2. Dovio A, Perazzolo L, Osella G, Ventura $M$, Termine $A$, Milano $E$, et al. Immediate fall of bone formation and transient increase of bone resorption in the course of high dose, short term glucocorticoid therapy in young patients with multiple sclerosis. J Clin Endocrinol Metab 2004; 89: 4923-8.

3. Hodgson SF. Corticosteroid-induced osteoporosis. Endocrinol Metabol Clin North Am 1990; 19: 95-111.

4. Boling EP. Secondary osteoporosis: underlying disease and the risk for glucocorticoid-induced osteoporosis. Clin Ther 2004; 26: 1-14.

5. Canalis E, Mazziotti G, Giustina A, Bilezikian JP. Glucocorticoid-induced osteoporosis: pathophysiology and therapy. Osteoporosis Int 2007; 18: 1319-28.

6. Rizzato G, Montemurro L. Reversibility of exogenous corticosteroid-induced bone loss. Eur Respir J 1993; 6: 116-9.

7. Compston A. Methylprednisolone and multiple sclerosis. Arch Neurol 1988; 45: 669-70.

8. Mcllwan HH. Glucocorticoid-induced osteoporosis: pathogenesis, diagnosis, and management. Prevent Med 2003; 36: 243-9.

9. Olbricht T, Benker G. Glucocorticoid-induced osteoporosis: pathogenesis, prevention and treatment, with special regard to the rheumatic diseases. J Intern Med 1993; 234: 237-44.

10. Baim S, Binkley N, Bilezikian JP, Kendler DL, Hans DB, Lewiecki EM, et al. Official Positions of the International Society for Clinical Densitometry and Executive Summary of the 2007 ISCD Position Development Conference. J Clin Denstom 2008; 11: 75-91.

11. Kraft GH, Freal JE, Coryell JK, Hanan CL, Chitnis N. Multiple sclerosis: early prognostic guidelines. Arch Phys Med Rehab 1981; 62: 54-8.

12. Scranton JA, Fogel NL, Erdman WJ. Evaluation of functional levels of patients during and following rehabilitation. Arch Phys Med Rehab 1970; 1-21.

13. Kurtzke JF. Rating neurological impairment in multiple sclerosis: an Expanded Disability Status Scale (EDSS). Neurology 1983; 33: 1444-52.

14. Mazziotti G, Angeli A, Bilezikian JP, Canalis E, Giustina A. Glucocorticoid-induced osteoporosis: an update. Trends Endocrinol Metab 2006; 17: 144-9.

15. Cosman F, Nieves J, Komar L, Ferrer G, Herbert J, Formica C, et al. Fracture history and bone loss in patients in MS. Neurology 1998; 51: 1161-5.

16. Formica CA, Cosman F, Nieves J, Herbert J, Lindsay R. Reduced bone mass and fat-free mass in women with multiple sclerosis: effects of ambulatory status and glucocorticoid use. Calcif Tissue Int 1997; 61: 129-33.

17. Schwid SR, Goodman AD, Puzas E, McDermott MP, Mattson $\mathrm{DH}$. Sporadic corticosteroid pulses and osteoporosis in multiple sclerosis. Arch Neurol 1996; 53: 753-7.

18. Zorzon $M$, Zivadinov $R$, Locatelli L, Giuntini $D$, Toncic $M$, Bosco $A$, et al. Long term effects of intravenous high dose methylprednisolone pulses on bone mineral density in patients with multiple sclerosis. Eur J Neurol 2005; 12: 550-6. 